Int. J. Dev. Biol. 64: 5-6 (2020)

https://doi.org/10.1387/ijdb.200146sg

\title{
A brief history of the Indian Society of Developmental Biologists (InSDB)
}

\author{
IQBAL AHMAD NIAZ|",1 and SURENDRA GHASKADBI ${ }^{*, 2}$ \\ ${ }^{1}$ Department of Zoology, University of Rajasthan, Jaipur, 302004, India \\ and ${ }^{2}$ Developmental Biology Group, MACS-Agharkar Research Institute, Pune, India
}

\begin{abstract}
The Indian Society of Developmental Biologists (InSDB) was founded in 1977 to promote regular interactions between all those interested in how organisms develop. Conferences and training workshops are regularly held in different parts of the country. In addition to Indian developmental biologists, InSDB invites participants from different parts of the globe every year, which allows exchange of ideas with the international community. The Society, which currently has over $\mathbf{4 0 0}$ members, holds meetings every two years. For updated information, visit http:// www.devbioindia.org.
\end{abstract}

KEY WORDS: India, ISDB, plant

The idea to have a scientific society of biologists working on areas of Development was first mooted at Leela Mulherkar's laboratory in the University of Poona (now Savitribai Phule Pune University: SPPU) around the mid-1970s. It was supported by several biologists working in other places in the country. The idea was converted into reality by the efforts of Suresh C. Goel, also of SPPU. Goel organised a mini-symposium on Developmental Biology at Utkal University, Bhubaneswar during the Annual Session of the Indian Science Congress Association in January 1977. A number of delegates to the Science Congress took part in this mini-symposium. In a meeting convened after the symposium, the participants converted themselves into a society and resolved to promote regular meetings and interactions between those doing research in any area of biology on problems related to the development of organisms. The Indian Society of Developmental Biologists was thus founded in January 1977 (Fig. 1). It was formally registered at Pune in 1979 with Department of Zoology, University of Poona, Pune, India as its official address. Suresh Goel was made the founding secretary of the society and he steered its activities for the next decade until his death.

The Society soon obtained affiliation to the International Society of Developmental Biologists (ISDB). The founders of the Society included Suresh C. Goel, Leela Mulherkar, P. N. Srivastava, P. Mohanty-Hejmadi, Sivatosh Mookerjee, U.S. Srivastava, Uma Devi, I. A. Niazi, M. K. Khare and several others. This Special Issue of the Int. J. Dev. Biol. contains Mohanty-Hejmadi's account of how Niazi influenced her research on retinoids and regeneration, and our description of the circumstances surrounding Niazi's pathbreaking experiment (Mohanty-Hejmadi, 2020; Ghaskadbi and Nanjundiah, 2020). The message of the Society spread across the country and attracted biologists at different universities and research institutes, who joined as life members.

During the first two decades following the formation of the Society, a series of symposia and workshops were organized at different universities and institutions. An Afro-Asian Conference and Symposium on Teaching and Research in Developmental Biology was held at Poona University, Pune in November 1982. It was co-sponsored by the International Society of Developmental Biologists and was inaugurated by its President, Tokindo S. Okada; P.N. Srivastava presided over the symposium. A large number of delegates from 14 Afro-Asian countries, as well as scientists from the USSR and UK, attended and deliberated on the future of developmental biology teaching and research in Afro-Asian countries. The symposium also served to introduce InSDB to the international developmental biology community.

The Indian Society of Developmental Biologists (InSDB) has continued to grow over the years (its Web address is http://www. devbioindia.org). Currently it has over 400 members including life, faculty and student members, with more joining each year as the pool of research laboratories in India where developmental

Abbreviations used in this paper: InSDB, Indian Society of Developmental Biologists; ISDB, International Society of Developmental Biologists.

\footnotetext{
*Address correspondence to: Surendra Ghaskadbi. Developmental Biology Group, MACS-Agharkar Research Institute, G.G. Agarkar Road, Pune-411 004, India. Phone: +91 20 25325063. Fax: +91 20 25651542. Email: smghaskadbi@ aripune.org ; ghaskadbi@ gmail.com - (iD https://orcid.org/0000-0002-7367-2049
}

\#Present address: D-2/2276, Vasant Kunj, New Delhi 110070, India 


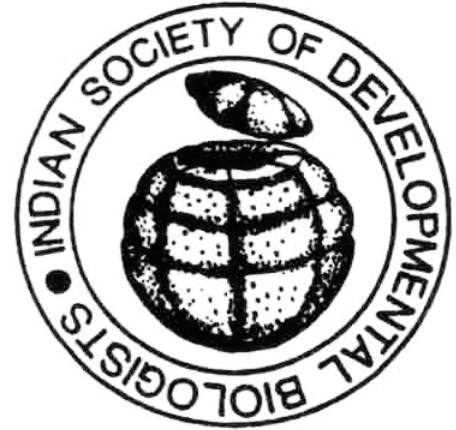

Fig. 1. Logo of Indian Society of Developmental Biologists (InSDB) founded in 1977.

biology problems are pursued, keeps growing. InSDB meetings are held once in two years, at which members discuss their work and exchange ideas. As everywhere, there has been a discernible shift in the way developmental biologists in India see their field, and that gets reflected in the meetings. At one time, conference talks and papers were mostly restricted to descriptive studies; over the years the work being presented has been overwhelmingly experimental, with approaches based on biochemistry and molecular biology beginning to dominate. Increasingly the aim is to decipher developmental mechanisms driving development using state-of-the-art techniques.

The current membership of InSDB includes workers from across organizations: full-time research workers as well as university and college faculty and, importantly, students from almost all parts of the country. An enthusiastic crop of new workers who became developmental biologists in the 1990s rejuvenated the field in India. The trend of young people entering the field, and also joining the InSDB, has led to the positive consequence that the average age of InSDB members and office bearers has come down significantly. The society had long remained the preserve of the animal kingdom, but now another major change is that plant biologists have joined the InSDB in large numbers in recent years.

A feature of InSDB meetings has been that every year scientists from other countries are invited to participate. Prominent representation has been from Japan, several European nations, Australia, New Zealand and the USA. This provides an opportunity to members, especially student members, to interact with developmental biologists from all over. The last meeting took place at Indian Institute of Technology, Kanpur in December 2018 and the next is due to take place in December 2020 at the National Centre for Biological Sciences, Bengaluru.

\section{References}

GHASKADBI, S. and NANJUNDIAH, V. (2020). One of the most significant discoveries in Developmental Biology from an Indian laboratory - Iqbal A. Niazi and the role of retinoids in limb regeneration. Int. J. Dev. Biol. 64: 71-97.

MOHANTY-HEJMADI, P (2020). Introduction of Developmental Biology at Utkal University, (Odisha, India). Int. J. Dev. Biol. 64: 59-64.

Further Related Reading, published previously in the Int. J. Dev. Biol.

5 th Congress of the Spanish Society of Developmental Biology

Jaume Baguñà

Int. J. Dev. Biol. (2007) 51: 91-96

First Meeting of the Portuguese Society for Developmental Biology (SPBD)

Raquel P. Andrade and Leonor Saúde

Int. J. Dev. Biol. (2007) 51: 177-182

A short history of the British Society for Developmental Biology

J M Slack

Int. J. Dev. Biol. (2000) 44: 79-83
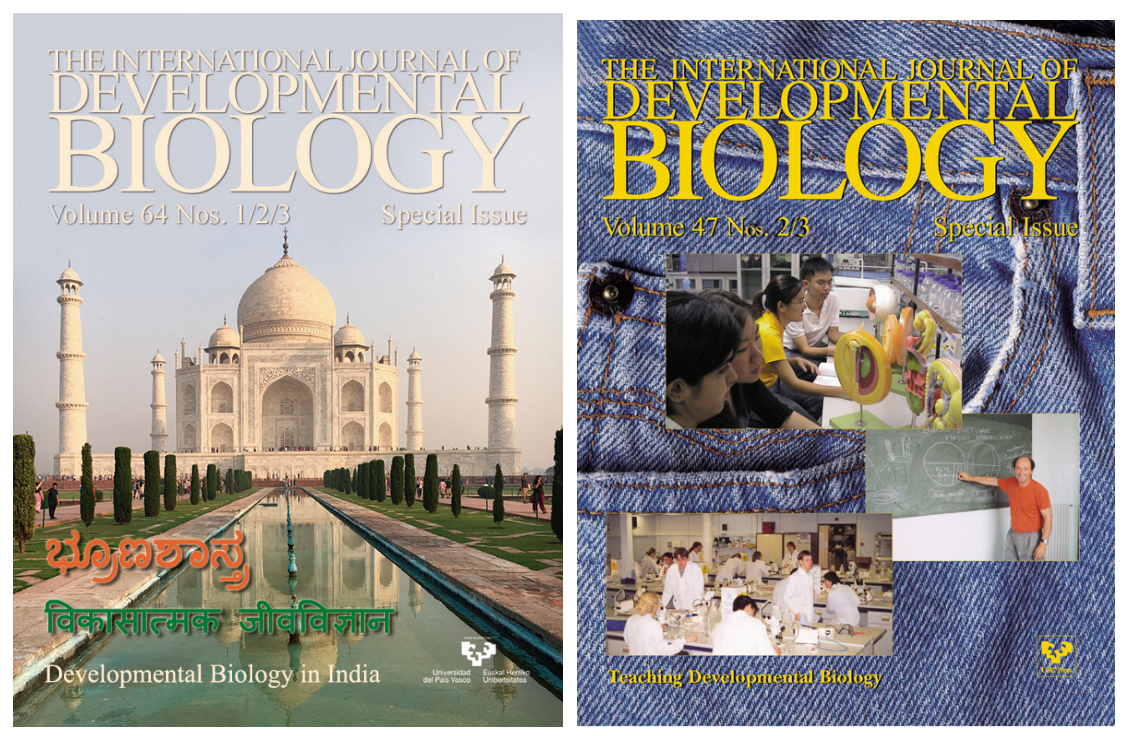